\title{
Reduction of Corky Root Infections on Greenhouse Tomato Crops by Soil Solarization in South Italy
}

A. Vitale and I. Castello, Dipartimento di Scienze e Tecnologie Fitosanitarie; G. Cascone, A. D'Emilio, and R. Mazzarella, Dipartimento di Ingegneria Agraria; and G. Polizzi, Dipartimento di Scienze e Tecnologie Fitosanitarie, Università degli Studi di Catania, 95123-Catania, Italy

\begin{abstract}
Vitale, A., Castello, I., Cascone, G., D’Emilio, A., Mazzarella, R., and Polizzi, G. 2011. Reduction of corky root infections on greenhouse tomato crops by soil solarization in South Italy. Plant Dis. 95:195-201.

Five greenhouse experiments were conducted in southeastern Sicily (Italy) from 2000 to 2009 to evaluate the effectiveness of soil solarization in reducing natural infections of tomato corky root caused by Pyrenochaeta lycopersici. Tests were performed with clear, traditional, and innovative plastic films and fumigant applications. In all the trials, soil solarization was effective in controlling corky root disease relative to an untreated control. Although inducing different thermal regimes in

the soil, the use of different greenhouse covering and mulching films for solarization proved effective in reducing corky root severity relative to the untreated control. Solarization reduced infections caused by $P$. lycopersici comparable with methyl bromide fumigation and greater than metham sodium and metham potassium. Among the tested films, green coextruded film may be most attractive because it can be left on after solarization as mulch.
\end{abstract}

Southeastern Sicily (Italy) is the most important area in Europe for greenhouse production of tomato (Lycopersicon esculentum L.). In $2009,3,556$ ha were cultivated, yielding 227,500 tons of tomato fruit (23), corresponding to nearly $42 \%$ of the total Italian tomato production.

Corky root, caused by Pyrenochaeta lycopersici (R.W. Schneid. $\&$ Gerlach), is among the most important soilborne tomato fungal diseases and is a serious problem in tomato greenhouse cultivation. This disease has been known in European greenhouses since the early 1960 s $(28,30,39)$ but only recently become more severe, principally due to the widespread use of monoculturing $(13,20)$. Specifically, in Mediterranean greenhouses, where the tomato crop is continuously cultivated for many years, the disease can cause 30 to $40 \%$ yield reduction, although Northern European production losses up to $75 \%$ have been observed (13).

$P$. lycopersici attacks the parenchyma tissues of the root system, causing brown lesions on primary and secondary roots, and rotting of small feeder roots (37). The lesions soon become dark brown and corky, with swollen, cracked, and fissured bark surfaces $(37,40)$. Severely affected plants show leaf yellowing, dwarfing, and massive root failure, while a number of adventitious roots are emitted from the crown. As a consequence, water and nutrient uptake of infected plants is compromised, leading to yield losses $(18,38)$. Although the fungus can produce solitary dark pycnidia (43), literature reports that the pathogen mainly survives in soil as microsclerotia in infected root debris for up to 5 years $(26,45,48,50)$. P. lycopersici is reported as a pathogen with an irreversible disease pattern; development of tomato corky root under protected monoculture increases severity annually, reaching a maximum after 7 years $(11,12,29)$. Thus, the main strategy used in the recent past to reduce yield losses due to corky root was preplant soil fumigation with methyl bromide (MB). According to the Montreal Protocol, MB has been recognized as an ozone-depleting chemical and it will be phased out worldwide by $2015(1,41)$. This has prompted the research of chemical, genetic, agronomic, and

Corresponding author: G. Polizzi, E-mail: gpolizzi@unict.it

Accepted for publication 6 October 2010.

doi:10.1094/PDIS-06-10-0418

(C) 2011 The American Phytopathological Society physical alternatives for the control of soilborne plant pathogens. In both protected and open field tomato cultivation, soil fumigants other than MB, such as chloropicrin, dazomet, and metham sodium, have been employed successfully against corky root disease $(2,3,32,40)$. Nevertheless, chemical treatments are expensive, devastate beneficial soil microflora, and cause environmental damage. Other current methods for controlling corky root have various limitations. For example, use of commercial tomato cultivars grafted onto rootstocks tolerant to $P$. lycopersici is effective but increases planting costs (21). Crop rotation can slowly reduce inoculum density in soil but is not always profitable. On the contrary, soil solarization is a sustainable and environmentally compatible technique for tomato production in greenhouses and has been shown to be effective in reducing many soilborne pathogens (27). The effectiveness of solarization depends on the amount, depth, and duration of increased soil temperature; the thermal sensitivity of the target organism; and the inoculum density of soilborne pathogens $(4,14,35,44,46,47)$. Success may also depend on the ability to integrate the approach with other pathogen control measures $(22,24,36)$. When solarization is carried out in a greenhouse with the vents kept closed (closed greenhouse), the temperature regimes in the soil depend on the characteristics of the mulching and covering materials, the physical properties and water content of the soil, and the climate of the area, as well as the shape and the dimensions of the greenhouse (7). The effectiveness of soil solarization for controlling corky root of tomato in closed greenhouses in Italy was demonstrated for the first time by Garibaldi and Tamietti (17).

Research on the use of greenhouse coverings and mulching films with innovative characteristics has been carried out to improve the efficacy or the sustainability of this technique. An objective was the use of innovative covering and mulching films having spectroradiometric properties able to enhance the greenhouse effect compared with traditional films. With regard to the improvement of sustainability without affecting the solarization effectiveness, the research focused on two main strategies. The first concerned the reduction of the amount of plastic either by lengthening the lifespan of films (using multiyear greenhousecovering materials or mulches to be retained on soil after solarization during the cultivation season) or by reducing the thickness of plastic sheets. The other strategy focused on the evaluation of biodegradable and photodegradable mulching films $(5,8,10,33$, $34,42,44)$. 
The objectives of this study were to (i) evaluate the performance of plastic films used for soil mulching in greenhouses in solarization treatments for controlling corky root and (ii) compare the effectiveness of soil solarization with one fumigation treatment. The present article reports the results of five greenhouse experiments carried out in four representative localities of tomato production in southeastern Sicily.

\section{Materials and Methods}

Solarization sites. Five experiments (I, II, III, IV, and V) in closed greenhouses were carried out in different sites representative of tomato production in Sicily during four different years: experiment I $\left(36^{\circ} 55^{\prime} \mathrm{N}, 14^{\circ} 28^{\prime} \mathrm{E}\right)$ in Vittoria, Ragusa province, during the cropping season 2000-01; experiment II $\left(36^{\circ} 49^{\prime} \mathrm{N}, 14^{\circ}\right.$ $\left.27^{\prime} \mathrm{E}\right)$ and experiment III $\left(36^{\circ} 49^{\prime} \mathrm{N}, 14^{\circ} 28^{\prime} \mathrm{E}\right)$ in Santa Croce Camerina, Ragusa province, during the cropping seasons 2002-03 and 2004-05, respectively; and experiments IV and V $\left(37^{\circ} 00^{\prime} \mathrm{N}\right.$, $14^{\circ} 20^{\prime} \mathrm{E}$ ) in Gela, Caltanissetta province, during the cropping season 2008-09. All of the experimental sites had a history of severe corky root incidence in tomato cultivated without rotation. The control of soilborne pathogens (including $P$. lycopersici) was previously achieved through the use of a preplant application of MB. Soil type, according to United States Department of Agriculture soil texture classification, was loamy sand in the experiment I and sand at the remaining locations.

Experimental designs, solarization, and planting. In all experiments, soil was leveled and irrigated up to field capacity (40 to 50 liters $\mathrm{m}^{-2}$ ) before solarization. Throughout the solarization period, no additional irrigation was applied and the greenhouses were kept closed. The solarization period ranged from 40 to 59 days.

During all of the trials, soil temperature was measured at 15 and $30 \mathrm{~cm}$ of depth in one plot of each treatment. Two platinum thermoresistance probes (PT100, model 108; Campbell Scientific Ltd., Shepshed, Lougborough, United Kingdom) were used for each depth. After the placement of probes, the film sheets were laid on the soil surface and their edges were buried up to $30 \mathrm{~cm}$ of depth. Furthermore, combined air temperature and relative humidity sensors (model RH1; Environmental Measurements Ltd., Sunderland, United Kingdom) and pyranometers (model MS-102; EKO Instruments Co., Ltd., Tokyo) for the measurement of global radiation flux were placed outside and inside the greenhouses. All the sensors were connected to data-loggers (CR10 and CR10X; Campbell Scientific Ltd.) reading measurements every $15 \mathrm{~s}$ and recording the corresponding average values every $30 \mathrm{~min}$.

In all experiments, treatments were arranged in a randomized complete block design (RCBD) with three to five replications.

After soil solarization, the mulching films, except the ones designed to be kept on soil during the cropping season, were removed and replaced with a conventional $50-\mu$ m-thick black polyethylene (PE) film (SI.SAC. S.p.a., Ragusa, Italy, in experiments I and II; Agriplast S.r.l., Vittoria, Ragusa, Italy, in experiments III, IV, and V). The same PE films were used to mulch all the plots that where kept uncovered during solarization. The tomato transplanting was always performed in double rows along the middle axis of each plot.

Experiment $I$. The trial was carried out in a single-span greenhouse with a wooden-concrete structure. The greenhouse was 60.0 by $12.0 \mathrm{~m}$ and was longitudinally oriented northwest to southeast. The greenhouse was covered by a $150-\mu$ m-thick ethylene-vinylacetate (EVA) film (SI.SAC. S.p.a.) several days prior to soil solarization.

Four soil treatments were used: (i) untreated control, (ii) MB fumigation $\left(40 \mathrm{~g} \mathrm{~m}^{-2}\right)$ injected into soil under a virtually impermeable film (VIF) (SI.SAC. S.p.a.) that was kept on soil for 8 days to allow molecule penetration and diffusion into soil, (iii) solarization with a $35-\mu$ m-thick EVA film (SI.SAC. S.p.a), and (iv) solarization with a $50-\mu \mathrm{m}$-thick photo-selective film (SI.SAC. S.p.a.) produced by the coextrusion of a layer of 25- $\mu$ m-thick uncolored EVA and a layer of $25-\mu \mathrm{m}$-thick green-colored EVA. The green EVA film was designed to be kept on soil after the end of soil solarization during the cropping season. The experiment was arranged in RCBD with four replications. Each experimental plot was 3.75 by $12.00 \mathrm{~m}$.

The solarization treatments lasted from 29 July to 7 September 2000. On 21 October 2000, seedlings of indeterminate tomato cv. ES200 or Lorybel F1 (ESASEM S.p.a., Verona, ITA) were planted in each plot. Corky root disease incidence and symptoms severity was evaluated on plant samples collected on 24 April 2001, 184 days after transplanting, at the end of the cropping season.

Experiment II. The trial was carried out inside a $66.5-\mathrm{by}-21.6-\mathrm{m}$ multispan wooden-concrete greenhouse oriented northwest to southeast. The greenhouse was covered by a $130-\mu$ m-thick EVA film (SI.SAC. S.p.a) prior to soil solarization. Six soil treatments were included in this greenhouse trial. Treatments included (i) untreated control, (ii) solarization with a $35-\mu \mathrm{m}$-thick uncolored EVA film, (iii) solarization with a $45-\mu$ m-thick green coextruded EVA film (SI.SAC. S.p.a), (iv) solarization with a $20-\mu$ m-thick uncolored LDPE-EVA-based multilayer film (PolyEur S.r.l., Benevento, Italy), (v) solarization with a $40-\mu \mathrm{m}$-thick white biodegradable starch-based film (Novamont, Novara, Italy), and (vi) MB fumigation $\left(40 \mathrm{~g} \mathrm{~m}^{-2}\right.$ ) (see rates described for experiment I).

Treatments were arranged in RCBD with four replications, with each plot 3.8 by $10.8 \mathrm{~m}$.

The solarization period lasted from 13 July to 22 August 2002. After solarization treatments, EVA and multilayer films were replaced by $50-\mu \mathrm{m}$-thick black PE film, while white biodegradable film was replaced by a $40-\mu \mathrm{m}$-thick black biodegradable starchbased film (Novamont S.p.a.) designed for the cropping season. On 4 November 2002, seedlings of indeterminate tomato cv. Jabot F1 (Seminis, The Netherlands) were transplanted in each plot. Corky root disease incidence and symptom severity were evaluated on plant samples collected on 22 May 2003, 201 days after tomato transplanting, at the end of the cropping season.

Experiment III. The trial was carried out inside a multispan 64.8 by $20.2 \mathrm{~m}$ wooden-concrete oriented east to west. The greenhouse was covered by a $200-\mu m$-thick EVA film (Agriplast S.r.l.), before soil solarization.

Four treatments were arranged in RCBD with five replications. Each experimental plot was 2.7 by $9.5 \mathrm{~m}$ and consisted of (i) untreated control, (ii) metham sodium fumigation (MS, 353 liters a.i. $\mathrm{ha}^{-1}$ ), (iii) metham potassium fumigation (MK, 350 liters a.i. ha ${ }^{-1}$ ), and (iv) solarization with a $35-\mu \mathrm{m}$-thick clear EVA film (Agriplast S.r.l.).

The plots were solarized from 9 August to 20 September 2004. MS and MK were both applied by pole injector and covered with LDPE film, (Agriplast S.r.1.) on 1 September 2004, after irrigation. On 20 September 2004, seedlings of tomato cv. Shiren (Cois 94, Italy), a cherry grape with indeterminate growth, were transplanted. Incidence and severity of corky root were evaluated on plant samples collected on 9 June 2005, 262 days after tomato transplanting, at the end of the cropping season.

Experiments $I V$ and $V$. Two trials were carried out in two twin multispan tunnel greenhouses, with steel structure, each sized 45.0 by $29.5 \mathrm{~m}$, oriented north to south.

The protocols to evaluate the effectiveness of different soil solarization films in controlling corky root infections for experiments IV and V were identical, except for the covering of each greenhouse, which was covered with a $150-\mu$ m-thick EVA (Agriplast S.r.1.) (experiment IV) and a $60-\mu \mathrm{m}$-thick polyamide-based film (Agriplast S.r.l.) (experiment V).

According to the experimental protocol, five different treatments were tested on soil in each greenhouse: (i) untreated control; (ii) solarization with a $55-\mu \mathrm{m}$-thick smoky gray photo-selective LDPE film (Agriplast S.r.l.), obtained with addition of lampblack; (iii) solarization with a $25-\mu \mathrm{m}$-thick green coextruded film (Agriplast S.r.l.); (iv) solarization with a $25-\mu \mathrm{m}$-thick clear LDPE film (Agriplast S.r.1.); and (v) solarization with a 25 - $\mu \mathrm{m}$-thick clear polyamide-based film (Agriplast S.r.1.).

The solarization treatments performed in both greenhouses were arranged in a RCBD with three replications. Each experimental plot was 3.7 by $14.5 \mathrm{~m}$. 
Solarization treatments lasted from 29 June to 27 August 2008. After the solarization period and film replacement, tomato seedlings cv. Francy F1 (De Reuters Seeds, The Netherlands) with indeterminate growth were transplanted on 6 September in both greenhouses. Incidence and severity of corky root were evaluated on plant samples collected on 26 January 2009, 141 days after tomato transplanting, at the end of cropping season.

Disease assessment and yield. The effectiveness of treatments was determined by calculating disease incidence (DI) and severity of plant symptoms (SS) at the end of the cropping season. To this aim, 20 to 30 plants were randomly selected from each plot, excluding border rows. An empirical 1-to-7 rating scale was used for SS evaluation, taking into account percentage of infected root surface, where $1=$ no symptoms and $2=1$ to $5,3=6$ to $10,4=11$ to $25,5=26$ to $50,6=51$ to 75 , and $7=$ more than $75 \%$ of infected root surface. The presence of $P$. lycopersici on damaged roots was confirmed on five plants for each plot by isolation in culture. The samples were washed, surface sterilized for $1 \mathrm{~min}$ in a sodium hypochlorite solution (1.2\% active chlorine), and rinsed twice with sterile distilled water. Twenty small fragments of symptomatic root tissue from each plant were plated onto selective Corky Root Medium (CRM) described by Grove and Campbell (19) and modified by Cascone et al. (8). Plates were incubated at $25^{\circ} \mathrm{C}$ for 15 days. The colonies that developed on the plates were examined periodically and P. lycopersici was identified on the basis of the presence of gray-sterile mycelium and morphological features. After the detection of the fungal pathogen, SS was definitively rated in each plot.

Table 1. Mean daily values of global radiation and air temperature

\begin{tabular}{lccccc}
\hline & \multicolumn{5}{c}{ Experiment } \\
\cline { 2 - 6 } Parameters $^{\mathbf{z}}$ & I & II & III & IV & V \\
\hline $\mathrm{R}_{\text {est }}\left(\mathrm{MJ} \mathrm{m}^{-2}\right)$ & 24.6 & 25.4 & 22.2 & 24.3 & 24.3 \\
$\mathrm{R}_{\text {in }}\left(\mathrm{MJ} \mathrm{m}^{-2}\right)$ & 16.0 & 15.1 & 13.9 & 17.1 & 17.1 \\
$\mathrm{~T}_{\text {est }}\left({ }^{\circ} \mathrm{C}\right)$ & 25.8 & 27.3 & 24.6 & 24.9 & 24.9 \\
$\mathrm{~T}_{\text {in }}\left({ }^{\circ} \mathrm{C}\right)$ & 38.6 & 56.5 & 40.8 & 36.4 & 36.1 \\
\hline
\end{tabular}

${ }^{\mathrm{z}} \mathrm{R}_{\text {est }}=$ outside global solar radiation, $\mathrm{R}_{\mathrm{in}}=$ inside global radiation, $\mathrm{T}_{\mathrm{est}}=$ outside air temperature, and $\mathrm{T}_{\mathrm{in}}=$ inside air temperature.
Yields in each plot were determined by the total weight (kilograms) of commercial tomato fruit per plant recorded during all the cropping season (cumulative harvests). Average yield per plant for each treatment were determined in experiments I, II, and III.

Statistical analyses. In all the experiments, the means of DI, SS index, and yield for each treatment were calculated, averaging corresponding values determined for each plot. Furthermore, analysis of variance (ANOVA; Statistica 7; Statsoft Inc.) was performed for DI and yield data. Percentage data concerning DI were transformed using arcsine $\left(\sin ^{-1}\right.$ square $\operatorname{root} x$ ) prior to statistical analysis. Mean values of DI and yield were compared through ANOVA for randomized complete block design. The corresponding mean values were separated by least significant difference test $(P \leq 0.05$ or 0.01$)$. Untransformed arithmetic means of DI are presented in the tables. Because an ordinal scale was adopted for disease severity assessment, SS data were analyzed according to the Kruskal-Wallis nonparametric one-way analysis (Statistica 7, Statsoft Inc.) followed by all possible pairwise comparisons using the Mann-Whitney test.

\section{Results}

Environmental conditions and soil temperatures. During the five greenhouse experiments, environmental conditions did not vary much from year to year (Table 1) and were representative of the mean seasonal values for the areas where the studies were conducted. Throughout the duration of the solarization treatments, there were few cloudy days and no precipitation occurred. The mean value of the daily global solar radiation flux ranged from $22.2 \mathrm{MJ} \mathrm{m}^{-2}$ in experiment III to $25.4 \mathrm{MJ} \mathrm{m}^{-2}$ in experiment II. Correspondingly, the mean value of daily global solar radiation inside the greenhouses ranged from $13.9 \mathrm{MJ} \mathrm{m}^{-2}$ in experiment III to $17.1 \mathrm{MJ} \mathrm{m}^{-2}$ in experiment IV. Mean values of outside air temperature ranged from $24.6^{\circ} \mathrm{C}$ in experiment III to $27.3^{\circ} \mathrm{C}$ in experiment II. Inside the greenhouses, the values of mean air temperature ranged from $36.1^{\circ} \mathrm{C}$ in experiments $\mathrm{V}$ to $56.5^{\circ} \mathrm{C}$ in the experiment II.

The number of hours during which the soil temperature exceeded threshold values from 38 to $48^{\circ} \mathrm{C}$ are reported in Table 2. In all experiments, the effect of solarization in increasing the soil

Table 2. Number of hours exceeding temperature thresholds

\begin{tabular}{|c|c|c|c|c|c|c|c|}
\hline \multirow[b]{3}{*}{ Experiment } & \multirow[b]{3}{*}{ Solarization film ${ }^{\mathrm{w}}$} & \multicolumn{6}{|c|}{ No. of hours exceeding temperature threshold } \\
\hline & & \multicolumn{3}{|c|}{ 15-cm depth } & \multicolumn{3}{|c|}{ 30-cm depth } \\
\hline & & $\mathbf{3 8}^{\circ} \mathrm{C}$ & $43^{\circ} \mathrm{C}$ & $48^{\circ}$ & $\mathbf{3 8}^{\circ} \mathrm{C}$ & $43^{\circ} \mathrm{C}$ & $48^{\circ} \mathrm{C}$ \\
\hline \multirow[t]{3}{*}{$\mathrm{I}$} & EVA & 894 & 406 & 23 & 911 & 228 & 0 \\
\hline & Green $^{x}$ & 624 & 226 & 0 & 778 & 0 & 0 \\
\hline & Control & 439 & 27 & 0 & 230 & 0 & 0 \\
\hline \multirow[t]{5}{*}{ II } & EVA & 914.5 & 811.5 & 329 & 900 & 809.5 & 49 \\
\hline & Green ${ }^{y}$ & 916 & 664.5 & 275 & 894.5 & 676.5 & 0 \\
\hline & Multi & 925.5 & 759.5 & 395.5 & 910.5 & 821.5 & 68 \\
\hline & Bio & 918.5 & 589 & 67 & 893 & 423.5 & 0 \\
\hline & Control & 761.5 & 311 & 0 & 799.5 & 0.5 & 0 \\
\hline \multirow[t]{2}{*}{ III } & EVA & 987 & 714.5 & 204 & 972.5 & 910.5 & 0 \\
\hline & Control & 676.5 & 182.5 & 0 & 826.5 & 0.5 & 0 \\
\hline \multirow{5}{*}{ IV } & Smoky gray & 1378 & 831 & 247.5 & 1353 & 741 & 0 \\
\hline & PE & 1382 & 894 & 383 & 1368.5 & 1029 & 0 \\
\hline & Green $^{2}$ & 1380.5 & 950.5 & 434.5 & 1354 & 1062.5 & 0 \\
\hline & Poly & 1382.5 & 980.5 & 459.5 & 1358.5 & 1019.5 & 0 \\
\hline & Control & 752.5 & 3.5 & 0.5 & 281 & 0 & 0 \\
\hline \multirow[t]{5}{*}{$\mathrm{V}$} & Smoky gray & 1354 & 821 & 290 & 1338 & 692 & 0 \\
\hline & PE & 1379 & 887 & 350 & 1346 & 1001 & 0 \\
\hline & Green $^{z}$ & 1367 & 917 & 319 & 1334 & 1015 & 0 \\
\hline & Poly & 1360 & 813 & 273 & 1348 & 798 & 0 \\
\hline & Control & 622 & 0 & 0 & 238 & 0 & 0 \\
\hline
\end{tabular}

${ }^{\mathrm{w}}$ EVA $=35$ - $\mu \mathrm{m}$-thick clear ethylene-vinyl-acetate $(\mathrm{EVA})$ film, Multi = 20- $\mu$-thick uncolored LDPE-EVA-based multilayer film, Bio = 40- $\mu$-thick white biodegradable starch-based film, Smoky gray $=55-\mu \mathrm{m}$-thick smoky gray photo-selective LDPE film, PE $=25-\mu \mathrm{m}-$ thick clear LDPE film, Poly $=20-\mu \mathrm{m}-$ thick clear polyamide-based film, and Control = unmulched soil.

${ }^{x}$ Green $=50-\mu m$-thick green coextruded EVA film.

${ }^{y}$ Green $=45-\mu \mathrm{m}$-thick green coextruded EVA film.

${ }^{\mathrm{z}}$ Green $=25-\mu \mathrm{m}$-thick green coextruded EVA film. 
temperature was evident when compared with the control (bare soil); in solarized soil, the number of hours for which temperatures exceeded $43^{\circ} \mathrm{C}$ was always greater than that achieved in bare soil. In detail, at $15 \mathrm{~cm}$ of depth, the number of hours during which soil temperature exceeded $43^{\circ} \mathrm{C}$ was 226 in green-mulched soil versus 27 in bare soil in experiment I and up to 980.5 in polyamide-based mulched soil versus 3.5 in the control in experiment IV. At $30 \mathrm{~cm}$ of depth, temperatures above $43^{\circ} \mathrm{C}$ were reached only in the solarized plots.

Disease incidence and symptom severity. There was a significant effect of soil treatment on mean DI and SS data among the disease rating classes in experiments I, II, and III (Tables 3-5) whereas, in experiments IV and V, statistically significant differences were detected only on the mean SS values (Tables 6 and 7).

In experiment I, a moderate level of SS caused by P. lycopersici was detected at the end of the cycle in the untreated plots. Under these conditions, the percentage of infected plants (DI) was significantly lower in plots solarized with EVA film and in plots fumigated with MB than in unmulched plots and in plots solarized with green coextruded film. SS values among soil treatments were significantly different, as indicated by $\chi^{2}$ and $P$ level (Table 3 ). In addition, differences between each treatment and control were all statistically significant. Moreover, mean SS was significantly lower in plots solarized with EVA film relative to MB-fumigated plots $(P$
$=0.0024)$ and in MB-treated plots relative to plots solarized with green coextruded film $(P<0.001)$.

A high level of corky root severity also occurred in experiment II. All soil treatments, including soil solarization performed with different films, significantly reduced mean DI and SS values relative to the untreated plots (Table 4). Conversely, no significant differences were observed for DI and SS in most pairwise combinations between different soil treatments, except for the comparison between $\mathrm{MB}$ and biodegradable film, where a significant effect $(P=0.015)$ was detected.

In experiment III, under conditions of moderate corky root SS, only solarization performed with EVA film significantly reduced the DI and SS values relative to the untreated control. No significant disease control was observed in plots fumigated with MS and MK (Table 5).

In both experiments IV and V, soil solarization treatments with all mulching films significantly reduced the percentage of root surface infected by $P$. lycopersici (mean SS) when compared with untreated plots (Tables 6 and 7), although a DI of $100 \%$ occurred in all experimental plots. The Mann-Whitney test run for all possible pairwise combinations of treatments for both experiments confirmed significantly lower SS values in all solarized plots compared with the controls, and different effectiveness among soil mulching films in corky root control.

Table 3. Effect of soil solarization treatments and methyl bromide fumigation on corky root disease incidence (DI), symptom severity (SS), and tomato yield in experiment $\mathrm{I}^{\mathrm{y}}$

\begin{tabular}{lccccc}
\hline Treatments $^{\mathbf{z}}$ & DI (\%) & Mean SS index (1-to-7 scale) & Median SS rating & Mean rank score & Yield (kg/plant) \\
\hline EVA & $85.0 \mathrm{a}$ & $2.52 \mathrm{a}$ & 3.0 & 134.94 & $2.94 \mathrm{~b}$ \\
MB & $89.2 \mathrm{a}$ & $2.84 \mathrm{~b}$ & 3.0 & 173.08 & $2.71 \mathrm{~b}$ \\
Green & $100 \mathrm{~b}$ & $3.46 \mathrm{c}$ & 3.0 & 255.47 & $3.84 \mathrm{~b}$ \\
Control & $100 \mathrm{~b}$ & $4.50 \mathrm{~d}$ & 4.5 & 398.50 & $1.64 \mathrm{a}$ \\
\hline
\end{tabular}

${ }^{y}$ Data are means of four replications (plots), each containing 30 tomato plants. Values followed by the same letters within a column are not significantly different according to the least significant difference test at $P=0.01$ for DI and $P=0.05$ for yield. Arcsine $\left(\sin ^{-1}\right.$ square root $x$ ) transformation was used on percentage data prior to analysis. Untransformed data are presented. Differences among rank sums of SS data for each treatment were analyzed with Kruskal-Wallis one-way analysis of variance by ranks followed by all pairwise multiple comparison with Mann-Whitney test; $\chi^{2}=262.62$ and $P$ values $<$ 0.001 indicate the significance of the Kruskal-Wallis test.

${ }^{\mathrm{z}} \mathrm{EVA}=35-\mu \mathrm{m}$-thick clear ethylene-vinyl-acetate $(\mathrm{EVA})$ film, $\mathrm{MB}=$ methyl bromide $\left(40 \mathrm{~g} \mathrm{~m}^{-2}\right)$, Green $=50-\mu \mathrm{m}$-thick green coextruded EVA film, and Control = unmulched soil.

Table 4. Effects of soil solarization and fumigation treatments on corky root disease incidence (DI), symptom severity (SS), and tomato yield in experiment II ${ }^{\mathrm{y}}$

\begin{tabular}{lccccc}
\hline Treatments $^{\mathbf{z}}$ & DI $(\boldsymbol{\%})$ & Mean SS index (1-to-7 scale) & Median SS rating & Mean rank score & Yield (kg/plant) \\
\hline MB & $65.00 \mathrm{a}$ & $1.96 \mathrm{a}$ & 2.0 & 175.83 & 2.75 \\
EVA & $71.25 \mathrm{a}$ & $2.29 \mathrm{ab}$ & 2.0 & 205.71 & 197.82 \\
Green & $71.25 \mathrm{a}$ & $2.19 \mathrm{ab}$ & 2.0 & 212.49 & 2.71 \\
Multi & $73.75 \mathrm{a}$ & $2.38 \mathrm{ab}$ & 2.0 & 224.46 & 2.78 \\
Bio & $70.00 \mathrm{a}$ & $2.54 \mathrm{~b}$ & 2.0 & 426.69 & 2.72 \\
Control & $100.0 \mathrm{~b}$ & $5.96 \mathrm{c}$ & 6.0 & 2.51 \\
\hline
\end{tabular}

y Data are means of four replications (plots), each containing 20 tomato plants. Values followed by the same letters within a column are not significantly different according to the least significant difference test at $P=0.05$ for DI. Arcsine ( $\sin ^{-1}$ square root $x$ ) transformation was used on percentage data prior to analysis. Untransformed data are presented. Differences among rank sums of SS data for each treatment were analyzed with Kruskal-Wallis one-way analysis of variance by ranks followed by all pairwise multiple comparison with Mann-Whitney test; $\chi^{2}=129.93$ and $P$ values $<0.001$ indicate the significance of the Kruskal-Wallis test.

${ }^{\mathrm{z}} \mathrm{MB}=$ methyl bromide, EVA $=35-\mu \mathrm{m}$-thick clear ethylene-vinyl-acetate $(\mathrm{EVA})$ film, Green $=45-\mu \mathrm{m}$-thick green coextruded EVA film, Multi $=20-\mu \mathrm{m}$-thick uncolored LDPE-EVA-based multilayer film, Bio $=40$ - $\mu \mathrm{m}$-thick white biodegradable starch-based film, and Control $=$ unmulched soil.

Table 5. Effects of soil solarization and fumigation treatments on corky root disease incidence (DI), symptom severity (SS), and tomato yield in experiment III ${ }^{\mathrm{y}}$

\begin{tabular}{lccccc}
\hline Treatments $^{\mathbf{z}}$ & DI $(\boldsymbol{\%})$ & Mean SS index (1-to-7 scale) & Median SS rating & Mean rank score & Yield (kg/plant) \\
\hline EVA & $74.0 \mathrm{a}$ & $2.14 \mathrm{a}$ & 2 & 82.01 & $1.38 \mathrm{ab}$ \\
MS & $100 \mathrm{~b}$ & $4.34 \mathrm{~b}$ & 4 & 249.50 & $1.47 \mathrm{ab}$ \\
MK & $100 \mathrm{~b}$ & $4.06 \mathrm{~b}$ & 4 & 228.52 & $1.60 \mathrm{~b}$ \\
Control & $100 \mathrm{~b}$ & $4.30 \mathrm{~b}$ & 4 & 241.97 & $1.31 \mathrm{a}$ \\
\hline
\end{tabular}

${ }^{y}$ Data are means of five replications (plots), each containing 20 tomato plants. DI and SS values followed by the same letters within a column are not significantly different according to the least significant difference test at $P=0.01$ for DI and $P=0.05$ for yield. Arcsine ( $\sin ^{-1}$ square root $x$ ) transformation was used on percentage data prior to analysis. Untransformed data are presented. Differences among rank sums of SS data for each treatment were analyzed with Kruskal-Wallis one-way analysis of variance by ranks followed by all pairwise multiple comparison with Mann-Whitney test; $\chi^{2}=51.70$ and $P$ values $<0.001$ indicate the significance of the Kruskal-Wallis test.

${ }^{\mathrm{z}} \mathrm{EVA}=35-\mu \mathrm{m}$-thick clear EVA film, MS = metham sodium, $\mathrm{MK}=$ metham potassium, and Control = unmulched soil. 
Under the greenhouse with EVA covering film (experiment IV), all pairwise combinations between soil-mulching films revealed that the SS values were higher in plots solarized with LDPE film relative to the smoky gray $(P<0.001)$, green coextruded $(P<$ $0.001)$, and polyamide film $(P<0.001)$.

In experiment $\mathrm{V}$, under the greenhouse covered with polyamidebased film, statistical analysis showed the same rank of effectiveness in corky root control for all pairwise combinations except for the comparison between green coextruded and LDPE film, where a significant effect $(P=0.0024)$ was observed.

Yield. Only in the soil solarization experiment I were effect on yields noted. An increase in yield of up to $73.1 \%$ was recorded in solarized plots with coextruded green film compared with the unmulched control. In experiments II and III, yield increases between 5.2 and $8.0 \%$ in solarized plots relative to the unmulched plots were not significantly different (Tables 3-5). However, in experiment III, only MK fumigation had significantly increased yield relative to the untreated plots (Table 5). Yield increases of 65.2 and $9.6 \%$ were recorded in plots fumigated with $\mathrm{MB}$ in experiments I and II (Tables 3 and 4), respectively, with significant differences only in experiment II.

\section{Discussion}

In each experiment, significant reductions in DI or SS of disease caused by $P$. lycopersici on tomato plants were detected in all solarized and MB-fumigated plots relative to those in control plots. However, the reduction of DI was limited because widespread disease symptoms were consistently observed in all the experiments. Significant reduction of DI was detected in the MB-fumigated and EVA-solarized plots in experiment I, in all treatments in experiment II, and only in solarized plots in experiment III. Differences in DI were not detected in experiments IV and V. With the exception of MS and MK fumigants, all treatments were effective in reducing disease SS when compared with untreated plots.

Soil solarization carried out during summer for 40 to 59 days in closed greenhouses under different conditions using both traditional and innovative films was effective in controlling tomato corky root in all experiments, according to preliminary studies $(8,17)$, although variations among mulching films were observed. Soil solarization is primarily related to different thermal regimes achieved into the soil but other factors can influence its effectiveness. Indeed, soil solarization is a hydrothermal process and variations in the moisture content of the soil under different mulching films could be responsible for different performances in controlling corky root $(9,31)$. In addition, these variable results could be related to the tomato cultivar, time of infection, and variation in soil microflora (15).

Regarding the thermal regimes achieved in the soil, the mean values of soil temperature ranged between 42 and $45^{\circ} \mathrm{C}$ for all mulching films and depths in experiments II, III, IV, and V. In ex-

Table 6. Effects of soil solarization treatments on corky root disease incidence (DI) and symptom severity (SS) under greenhouse with EVA covering in experiment IVy

\begin{tabular}{lccc}
\hline Treatments $^{\mathbf{z}}$ & $\begin{array}{c}\text { Mean SS index } \\
\text { (1-to-7 scale) }\end{array}$ & $\begin{array}{c}\text { Median SS } \\
\text { rating }\end{array}$ & $\begin{array}{c}\text { Mean rank } \\
\text { score }\end{array}$ \\
\hline Smoky gray & $4.03 \mathrm{a}$ & 4 & 135.19 \\
PE & $4.53 \mathrm{~b}$ & 5 & 189.86 \\
Green & $3.94 \mathrm{a}$ & 4 & 122.39 \\
Poly & $4.00 \mathrm{a}$ & 4 & 131.89 \\
Control & $6.67 \mathrm{c}$ & 7 & 323.17 \\
\hline
\end{tabular}

${ }^{y}$ Data are means of three replications (plots), each containing 24 tomato plants. Statistical analysis using Kruskal-Wallis one-way analysis of variance by ranks followed by all pairwise multiple comparisons with Mann-Whitney test; $\chi^{2}=170.91$ and $P$ values $<0.001$ indicate the significance of the Kruskal-Wallis test.

${ }^{\mathrm{z}}$ Smoky gray $=55-\mu \mathrm{m}$-thick smoky gray photo-selective LDPE film, PE $=$ $25-\mu \mathrm{m}$-thick clear LDPE film, Green $=25-\mu \mathrm{m}$-thick green coextruded ethylene-vinyl-acetate (EVA) film, Poly $=20-\mu \mathrm{m}$-thick clear polyamidebased film, and Control $=$ unmulched soil. periment I, mean values of soil temperature under the different mulching films were lower than the corresponding ones in the other experiments, ranging from 39.3 to $42.4^{\circ} \mathrm{C}$. It is likely that this circumstance was determined by the greenhouse type, characterized by small covered surface, poor closure, and shadowing from the wooden-concrete structure.

In experiments I and II, both solarization with all mulching films (traditional and innovative) and fumigation with MB proved effective in controlling corky root on tomato plants relative to controls. However, solarization with green coextruded film was less effective in controlling tomato corky root than other treatments in experiment I, and solarization with biodegradable starch-based film was less effective than MB fumigation in experiment II. This could be due to a lower number of hours during which soil temperature exceeded the thresholds of $38^{\circ} \mathrm{C}$ (in experiment I) and $43^{\circ} \mathrm{C}$ (in experiments I and II) compared with those under EVA film. Good performance of solarization with green coextruded film for reducing SS values was detected in experiments II, IV, and V. Similarly satisfactory results on disease control were observed for solarization with the innovative multilayer (experiment II), smoky gray, and polyamide films (experiments IV and V).

It is clear that soil solarization is able to provide control of corky root comparable to that achieved with MB fumigation. Indeed, the reduction of corky root infections on tomato plants detected in EVA-solarized plots (SS values) was higher than that obtained in fumigated plots in experiment I. Solarization can control corky root in closed greenhouses and can be considered as a valid alternative to $\mathrm{MB}$ in this region, as reported by others $(6,15,49)$.

The failure of MS and MK in controlling corky root in experiment III is not in accordance with the findings of Bogoescu et al. (2), who reported a good effectiveness of MS against $P$. lycopersici on protected crops in Romania. For this reason, and because effectiveness of this fumigant was ascertained in controlling other soilborne pathogens of tomato, these results should be considered as preliminary $(16,25)$. Thus, further studies should be carried out in pedoclimatic conditions of South Italy to determine whether the application of MS and MK at low doses in combination with soil solarization would improve the effects of physical treatments against tomato corky root (51).

The effect of solarization on total yield of tomato fruit for different experiments was variable. In experiment I, all solarization treatments increased yield, which was associated with decreased DI and SS values relative to the untreated control. In contrast, in experiment II, no significant differences were detected among solarized, fumigated, and untreated plots whereas, in experiment III, tomato yield in plots solarized with EVA was comparable with those obtained in both fumigated and untreated plots. The observed variability could be related to the tomato cultivar, fertilization program, and time of infection. Each of these factors can affect tomato yield and, when taken together,

Table 7. Effects of soil solarization treatments on corky root disease incidence (DI) and symptom severity (SS) under greenhouse with polyamide covering in experiment $\mathrm{V}^{\mathrm{y}}$

\begin{tabular}{lccc}
\hline Treatments $^{\mathbf{z}}$ & $\begin{array}{c}\text { Mean SS index } \\
\text { (1-to-7 scale) }\end{array}$ & $\begin{array}{c}\text { Median SS } \\
\text { rating }\end{array}$ & $\begin{array}{c}\text { Mean rank } \\
\text { score }\end{array}$ \\
\hline Smoky gray & $4.17 \mathrm{ab}$ & 4 & 137.28 \\
PE & $4.36 \mathrm{~b}$ & 4 & 158.61 \\
Green & $4.14 \mathrm{a}$ & 4 & 128.67 \\
Poly & $4.33 \mathrm{ab}$ & 4 & 151.25 \\
Control & $6.56 \mathrm{c}$ & 7 & 320.28 \\
\hline
\end{tabular}

${ }^{\mathrm{y}}$ Data are means of three replications (plots), each containing 24 tomato plants. Statistical analysis using Kruskal-Wallis one-way analysis of variance by ranks followed by all pairwise multiple comparisons with Mann-Whitney test; $\chi^{2}=130.79$ and $P$ values $<0.001$ indicate the significance of the Kruskal-Wallis test.

${ }^{\mathrm{z}}$ Smoky gray $=55-\mu \mathrm{m}$-thick smoky gray photo-selective LDPE film, PE = $25-\mu \mathrm{m}$-thick clear LDPE film, Green $=25-\mu \mathrm{m}$-thick green coextruded ethylene-vinyl-acetate (EVA) film, Poly $=20-\mu \mathrm{m}$-thick clear polyamidebased film, and Control = unmulched soil. 
could cause considerable deviation in average yield observed in the experiment I.

The results of the present work show that soil solarization effectively managed corky root of tomato and would be compatible with normal agronomic practices developed for tomato production in protected crops. The sustainability of soil solarization could be further increased by using innovative materials. The use of biodegradable mulches that allow complete elimination of plastic is very promising, as is the development of biodegradable films which endure for longer periods. Among the tested films, the use of green coextruded film could be particularly attractive because it can be left on after the solarization period as mulch for extended weed control and increased soil temperature during early-season root development.

Further research regarding greenhouse-covering films should be performed to confirm whether reduction of plastic waste is possible by using long-life films, as suggested by those that are polyamide based, which seem to induce thermal regimes in solarized soil very similar to those obtained under cover with EVA film. In addition, further investigations are also necessary to evaluate long-term performance of this film after additional treatments of solarization. This innovation goes together with a technological shift of greenhouses in the Mediterranean basin from wood and concrete to steel-frame structure. This change is necessary to overcome the problem of the structural decay in wooden-concrete greenhouses due to high air temperatures reached during solarization, and could contribute further to adoption of this technique.

\section{Acknowledgments}

This research was partially supported by PROM Research Project "Potenziare la Competitività di Orticole in Aree Meridionali" from Italian Ministero delle Politiche Agricole, Alimentari e Forestali.

\section{Literature Cited}

1. Albritton, D. L., and Watson, R. T. 1992. Methyl bromide and the ozone layer; a summary of current understanding. Pages 3-18 in: Methyl Bromide: Its Atmospheric Science, Technology, and Economics, Montreal Protocol Assessment Supplement. R. T. Watson, D. L. Albritton, S. O. Anderson, and S. Lee-Bapty, eds. United Nations Environment Programme, Nairobi, Kenya.

2. Bogoescu, M., Gullino, M. L., Minuto, A., and Amadio, A. 2005. Alternatives to methyl bromide in Romanian protected crops. Acta Hortic. 698:315320

3. Campbell, R. N., Schweer, V. H., and Hall, D. H. 1982. Corky root of tomato in California caused by Pyrenochaeta lycopersici and control by soil fumigation. Plant Dis. 66:657-661.

4. Camprubi, A., Estaùn, V., El Bakali, M. A., Garcia-Figueres, F., and Calvet, C. 2007. Alternative strawberry production using solarization, metham sodium and beneficial soil microbes as plant protection methods. Agron. Sustain. Dev. 27:179-184.

5. Candido, V., Miccolis, V., Castronuovo, D., and Manera, C. 2007. Eco-compatible plastic films for crop mulching and soil solarization in greenhouse. Acta Hortic. 761:513-519.

6. Cartia, G. 1989. La solarizzazione del terreno:esperienze maturate in Sicilia. Inf. Fitopatol. 5:49-52.

7. Cascone, G., Arcidiacono, C., and D'Emilio, A. 1999. Influenza dell'apprestamento di protezione e della natura del terreno sui regimi termici della solarizzazione. Pages 137-148 in: Proc. Conf. "Le colture protette:aspetti agronomici, territoriali e tecnico-costruttivi”. Ragusa, Italy. (In Italian.)

8. Cascone, G., Polizzi, G., D'Emilio, A., and Grillo, R. 2000. Effectiveness of greenhouse soil solarization with different plastic mulches in controlling corky root and root-knot on tomato plants. Acta Hortic. 532:145-150.

9. DeVay, J. E. 1991. Historical review and principles of soil solarization. Pages 1-15 in: Soil Solarization. FAO Plant Prot. Prod. Pap. 109. J. E. DeVay, J. J. Stapleton, and C. L. Elmore, eds. FAO, Rome.

10. DeVay, J. E. 1991. Use of soil solarization for control of fungal and bacterial plant pathogens including biocontrol. Pages 79-93 in: Soil Solarization. FAO Plant Prod. Prot. Pap. 109. J. E. DeVay, J. J. Stapleton, and C. L. Elmore, eds. FAO, Rome.

11. Ebben, M. H. 1974. Brown root rot of tomato. Pages 127-135 in: Annual Report Glasshouse Crops Research Institute 1973. Littlehampton, England.

12. Ebben, M. H., and Last, F. T. 1975. Incidence of root rots-their prediction and relation to yield losses: a glasshouse study. Pages 6-10 in: Biology and Control of Soilborne Plant Pathogens. G. W. Bruehl, ed. American Phytopathological Society, St. Paul, MN.

13. Forsberg, A. S., Sahlström K., and Ögren, E. 1999. Rotröteproblem i ekolo- gisk odling. Jordbruksinformation 12. Jordbruksverket, Jönköping, Sweden. (In Swedish.)

14. French-Monar, R. D., Jones, J. B., Ozores-Hampton, M., and Roberts, P. D 2007. Survival of inoculum of Phytophthora capsici in soil through time under different soil treatments. Plant Dis. 91:593-598.

15. Gamliel, A. 2000. Soil amendments: a non chemical approach to the management of soilborne pest. Acta Hortic. 532:39-47.

16. Garibaldi, A., Baudino, M., Minuto, A., and Gullino, M. L. 2008. Effectiveness of fumigants and grafting against tomato brown root rot caused by $\mathrm{Col}$ letotrichum coccodes. Phytoparasitica 36:483-488.

17. Garibaldi, A., and Tamietti, G. 1983. Attempts to use soil solarization in closed glasshouses in Northern Italy for controlling corky root of tomato. Acta Hortic. 152:237-243.

18. Goodenough, P. W., and Maw, G. A. 1973. Effects of Pyrenochaeta lycopersici infection on nutrient uptake by tomato plants. Ann. Appl. Biol. 73:339347.

19. Grove, G. G., and Campbell, R. N. 1987. Host range and survival in soil of Pyrenochaeta lycopersici. Plant Dis. 71:806-809.

20. Hasna, M. K., Ögren, E., Persson, P., Mårtensson, A., and Rämert, B. 2009 Management of corky root disease of tomato in participation with organic tomato growers. Crop Prot. 28:155-161.

21. Ioannou, N. 2001. Integrating soil solarization with grafting on resistant rootstocks for management of soil-borne pathogens of eggplant. J. Hortic. Sci. Biotechnol. 76:396-401.

22. Israel, S., Mawar, R., and Lodha, S. 2005. Soil solarization, amendments and biocontrol agents for the control of Macrophomina phaseolina and Fusarium oxysporum f. sp cumini in arid soils. Ann. Appl. Biol. 146:481491.

23. Istat, Istituto Nazionale di Statistica, 2009. Table C34-Area (ares) and production (quintals): egg-plant, melon, red pepper, tomato, courgette. Data by province. Rome.

24. Jayaraj, J., and Radhakrishnan, N. V. 2008. Enhanced activity of introduced biocontrol agents in solarized soils and its implications of the integrated control of tomato damping-off caused by Pythium spp. Plant Soil 304:189197.

25. Jones, J. P., Gilreath, J. P., Overman, A. J., and Noling, J. W. 1996. Control of soilborne diseases of mulched tomato by fumigation. Proc. Fla. Stn. Hortic. Soc. 108:201-203.

26. Kartheuser, V. 1988. Biology of the pathogen of tomato corky root disease and possibilities for its control. Gartenbau 35:236-237.

27. Katan, J., and DeVay, J. E. 1991. Soil Solarization. J. Katan and J. E. DeVay, eds. CRC Press, Boca Raton, FL.

28. Last, F. T., and Ebben, M. H. 1966. The epidemiology of tomato brown root rot. Ann. Appl. Biol. 57:95-112.

29. Last, F. T., Ebben, M. H., Hoare, R. C., Turner, E. A., and Carter, A. R. 1969. Build-up of tomato brown root rot caused by Pyrenochaeta lycopersici Schneider and Gerlach. Ann. Appl. Biol. 64:449-459.

30. Last, F. T., Ebben, M. H., Rothwell, J. B., and Jones, D. A. G. 1968. Effects of cultural treatments on the incidence of, and damage done by, tomato brown root rot. Ann. Appl. Biol. 62:55-75.

31. Mahrer, Y. 1979. Prediction of soil temperature of a soil mulched with transparent polyethylene. J. Appl. Meteorol. 18:1263-1267.

32. Malathrakis, N. E., and Kambourakis-Tzagaroulakis, E. 1989. Control of tomato corky root rot by soil solarization in combination with soil fumigation. Acta Hortic. 255:205-211.

33. Malathrakis, N. E., and Loulakis, M. D. 1989. Effectiveness of the type of polyethylene sheet on soil solarization. Acta Hortic. 255:235-241.

34. Manera, C., Margiotta, S., Di Muro, E., and Gatta, G. 2002. Experimental tests on innovative and biodegradable films for solarization soil in a site of south Italy. Acta Hortic. 578:363-371.

35. McLean, K. L., Swaminathan, J., and Stewart, A. 2001. Increasing soil temperature to reduce sclerotial viability of Sclerotium cepivorum in New Zealand soils. Soil Biol. Biochem. 33:137-143.

36. Minuto, A., Spadaro, D., Garibaldi, A., and Gullino, L. 2006. Control of soil-borne pathogens of tomato using a commercial formulation of Streptomyces griseoviridis and solarization. Crop Prot. 25:468-475.

37. Pohronezny, K. L., and Volin, R. B. 1991. Corky root rot. Pages 12-13 in: Compendium of Tomato Diseases. J. B. Jones, J. P. Jones, R. E. Stall, and T. A. Zitter, eds. American Phytopathological Society, St. Paul, MN

38. Polley, R. W. 1985. The relationship between brown and corky root caused by Pyrenochaeta lycopersici and yield loss in tomatoes established by the use of artificially infested soils. Plant Pathol. 34:502-509.

39. Preece, T. F. 1964. Observations on the corky root disease of tomatoes in England. Trans. Br. Mycol. Soc. 47:375-379.

40. Punithalingam, E., and Holiday, P. 1973. Pyrenochaeta lycopersici. CMI Description of Pathogenic Fungi and Bacteria, No. 398. Commonwealth Agricultural Bureau, Kew, UK.

41. Ristaino, J., and Thomas, W. 1997. Agriculture, methyl bromide and the ozone hole can fill the gaps? Plant Dis. 81:964-977.

42. Russo, G., Candura, A., and Scarascia-Mugnozza, G. 2005. Soil solarization with biodegradable plastic film: two years of experimental tests. Acta Hortic. 691:717-724.

43. Schneider, R., and Gerlach, W. 1966. Pyrenochaeta lycopersici nov. spec., der Erreger der Korkwurzelkrankheit der Tomate. Phytopathol. Z. 56:117 
122. (In German.)

44. Scopa, A., Candido, V., Dumontet, S., and Miccolis, V. 2008. Greenhouse solarization: effects on soil microbiological parameters and agronomic aspects. Sci. Hortic. 116:98-103.

45. Shishkoff, N., and Campbell, R. N. 1990. Survival of Pyrenochaeta lycopersici and influence of temperature and cultivar resistance on the development of corky root of tomato. Plant Dis. 74:889-894.

46. Souza, N. L. 1994. Solarização do solo. Summa Phytopathol. 20:3-15.

47. Tamietti, G., and Valentino, D. 2006. Soil solarization as an ecological method for the control of Fusarium wilt of melon in Italy. Crop Prot. 25:389-397.
48. Termohlen, G. P. 1962. On corky root of tomato and the corky root fungus. Tijdschr. Plantenziekten 68:295-365.

49. Tjamos, E. C., and Faridis, A. 1980. Control of soilborne pathogens by solar heating in plastic houses. Pages 82-84 in: Proc. 5th Congr. Meditterr. Phytopathol. Union. Patras (GR).

50. White, J. G., and Scott, A. C. 1973. Formation and ultrastructure of microsclerotia of Pyrenochaeta lycopersici. Ann. Appl. Biol. 73:163-166.

51. Yucel, S., Ozarslandan, A., Colac, A., Ay, T., and Can, C. 2007. Effect of solarization and fumigant applications on soilborne pathogens and root-knot nematodes in greenhouse-grown tomato in Turkey. Phytoparasitica 35:450456. 